\title{
Driving Innovation: Reviewing the Role of Rewards
}

\author{
Said Juma Al Darmaki ${ }^{*}$, Rosmini Omar ${ }^{1}$ (), Wan Khairuzzaman Wan Ismail ${ }^{2}$ \\ ${ }^{1}$ Azman Hashim International Business School, Universiti Teknologi Malaysia, Kuala Lumpur, Malaysia \\ ${ }^{2}$ Sulaiman Al Rajhi School of Business, Sulaiman Al Rajhi Colleges, Al Bukayriyah, KSA \\ Email: *saidaldarmaki@gmail.com
}

How to cite this paper: Al Darmaki, S.J., Omar, R. and Ismail, W.K.W. (2019) Driving Innovation: Reviewing the Role of Rewards. Journal of Human Resource and Sustainability Studies, 7, 406-415. https://doi.org/10.4236/jhrss.2019.73027

Received: August 7, 2019

Accepted: September 2, 2019

Published: September 5, 2019

Copyright () 2019 by author(s) and Scientific Research Publishing Inc. This work is licensed under the Creative Commons Attribution International License (CC BY 4.0).

http://creativecommons.org/licenses/by/4.0/

(c) (i) Open Access

\begin{abstract}
The role of rewards in promoting innovation has received considerable attention in both theory and practice. The fact that rewards have a positive impact on promoting innovation is well established. However, this relationship is complex since different types of rewards are suited for various kinds and stages of innovation. Further, an alternate view undermines the role of rewards in promoting innovation. Through an exhaustive literature review, this study illustrates the complex relationship between rewards and innovation as well as the role of rewards in promoting innovation. This analysis throws light on the utility of various rewarding practices in promoting innovation. Thus, understanding the complexities of rewards systems for engaging talents in processes of creativity and innovation reflects the needs to design rewards systems, which strategically and ethically fits any organizational entity. Hence, both theorists and practitioners need a more holistic approach in designing a dynamic rewards system that encompasses issues of role, timing and magnitude of the rewards in order to drive innovation.
\end{abstract}

\section{Keywords}

Rewards, Innovation, Creativity, Literature

\section{Introduction}

Throughout the past and current decades, a plethora of research enlightens the relationship between rewards and innovation [1] [2] [3] [4]. Rewards are known to drive innovation [5]. Research explains that reward plays a significant role in the motivation of employees since it creates a certain degree of excitement among employees, thus leading to the development of innovation culture within the organization [6]. However, this relationship between rewards and innovation 
is not a straightforward one. Considering that innovation varies in degree and types, this study highlights that various types of rewards impact on different types of innovation. Further, considering the existence of a profusion of rewards systems, this study through an exhaustive literature review, shows that different types of rewards are linked to various stages of innovation. Finally, the study draws the attention to the studies that are critical of the relationship between rewards and innovation. This study therefore informs researches and practitioners on the utility of various rewards and provides a holistic understanding of the complex relationship between rewards and innovation.

Two types of rewards are primarily argued to impact innovation. These include extrinsic rewards consisting of financial benefits and intrinsic rewards expressed through praise and recognition [7]. Even though both these rewarding practices are often used interchangeably, they are different procedures with different benefits. Each type of reward can affect the success of innovative programs within organizations and their ability to influence innovation remains a contentious issue [8]. On the other hand, the literature continues to debate on the usefulness of various rewards in promoting innovation in firms and question the impact of rewards on creativity and innovation [9] [10]. Specific works argue that rewards do not adequately benefit firms in promoting innovation. They contend that financial rewards particularly are inept in generating quality ideas and innovative outputs. To illustrate, researchers argued that percentage of ideas that result into innovation is an important indicator of innovation [11] [12]. A survey of literature showed that most of the innovation indicators relate to innovation outputs rather than ideation and developmental stages of innovation. Hence, financial rewards may be ineffective, if ideas do not have the potential to qualify as "go-to-market" category. The focus of such reward systems shifts the focus on financial benefits rather than quality inputs and hence compromises innovation quality [13].

There is existing literature which adequately explains the role of rewards and associated risks in managing and improving innovation portfolios of organizations [14]. Such contrasting arguments reflect three decades of studies that have yet to mature into a unified theory and practice on the impact of rewards on creativity and innovation [15]. Furthermore, there is divergence and eclipse in exploring the process of how the role of rewards could specifically induce individual creativity as well as establishing a strong connection between the two aspects [10]. Innovation starts with creativity and if creativity is missing innovation is difficult to witness [16] [17]. Researchers also argue whether creativity should be rewarded (mainly ideas) or innovation. Therefore, the literature continues to debate the role of rewards in promoting creativity and innovation. This study throws light on various perspectives related to various rewards and utility of rewards in promoting innovation. The intention is to inform future academic research and managerial practice for designing rewards for innovation. In doing so, the study has its limitations. The literature that informs this study has been 
cited from different countries and cultures. A general observation of these studies does not provide a rich context to these rewarding practices, which can vary across countries and cultures. A second limitation of the study is that it looks only at various types of rewards and their relationship with innovation, which in practice may not explain the entirety of the observed phenomenon. A combination of factors along with rewards may promote innovation, which is not be accounted in this study. Finally, considering the depth and breadth of research on the topic, only those literatures have been chosen that meet the objectives of the study and various other nuances in this relationship could not be accommodated in this study. The rest of the paper is organized as follows. The next section provides a detailed analysis of the complex relationship between rewards and innovation, followed by conclusions and implications of the study.

\section{Literature Review}

The literature linking rewards with innovation is in abundance. Since the focus of the study was to understand the complex relationship between rewards and innovation, only the literatures that highlight the utility of rewards or undermine this relationship were included in this study. Further, studies that explain the varied nature of rewards and link them various types and stages in innovation found representation in this study.

Innovation is a key competency that allows firms to achieve competitive advantage [18]. Innovation can be defined as the creation of value from ideas [19]. The process of innovation involves acquiring, disseminating and using new or the existing knowledge [20]. It starts with generation of ideas and subsequently entering innovation development process [21] [22]. It usually leads to the development of new products, services and improvement of processes [23]. Both the stages of creativity and innovation require contribution from employees and efforts that are not normally associated with routine jobs. Therefore, in order to develop individual initiatives from employees, rewards become important stimuli.

Financial rewards involve cash prizes that are offered to the employees to encourage their contribution towards innovation [4]. Financial rewards are usually offered in terms of a fixed sum of money or a specific percentage. They can sometimes be through profit sharing or a bonus program [24]. However, financial rewards can be problematic especially when considering the ability of an organization to sustain it over time [20]. Sustaining financial rewards for an organization over a long period may be challenging. Financial rewards may also stifle innovation culture in the organization as the participation that is based on personal gain [25]. [24] argues that non-financial incentives can create a significant impact on innovation. Designing rewards for innovation is also challenging as measurement of innovation itself is puzzling and most organizations struggle to develop a comprehensive innovation measurement process [12].

A reward is a vital part of the creation of a sustainable and innovation environ- 
ment within the organization. The innovation process starts by encouraging communication and transparency between the employees and the management. This is a critical factor in building trust by encouraging employees to embrace innovation in the organization since it is vital for creating an open environment where employees can freely contribute their ideas without fearing anything hence enhancing the free flow of ideas [26]. Even though rewards are essential in keeping the employees motivated, it is the recognition of employees that creates a truly innovative culture [27]. [23] [28] also support the view that employees need to be rewarded so that a culture of creativity and innovation is built.

It is essential for organizations to keep in mind that only those employees who are contributing towards the anticipated outcomes need to be recognized and rewarded in the long run [29]. Another factor to consider is the size of the reward. In an organization, innovation tends to be a team-based practice. Offering individuals with substantial financial rewards could set them up against one another. It is vital for an organization to be cautious not to initiate rivalry within employees. It is crucial for the whole team that is pursuing innovation in the organization to be rewarded rather than rewarding individuals [29]. To achieve innovation within the organization, it is essential for the organization to base its reward system on performance [30]. Most managers, who run a fair system of reward, tend to achieve a high degree of innovation as opposed to those whose reward system is unfair. Rewarding an employee is a way of motivating them to be more innovative as a reward can cause satisfaction among the employees which have a direct effect on the performance of employees as far as innovation is concerned [31].

The literature on rewards for innovation has different views on the usefulness, practicality, nature, and size of rewards. Table 1 depicts the diverse views of researchers on rewards and innovation.

\section{Conclusion and Implications}

The literature shows divergent views on rewards for innovation. Although there is a broader level of convergence that rewards are necessary for promoting innovation, the points of debate revolve around what and when should be innovation rewarded. Innovation is a long process and starts with ideas, developmental stages and result in innovation. Previous work trails the critical timing or stage of rewarding employees. Based on the discussion in the literature, it seems that innovation rewards programs become ineffective when only a particular stage of innovation is rewarded. Most common examples include the idea generation stage. Firms should not only design rewards systems for different stages of innovation, but also design different types of rewards for different stages of innovation. Further, the debate on what should be considered as rewards is closely linked to the question of when the efforts for innovation arecritically needed. If firms design rewards for just the "efforts" of say generating ideas or developing prototypes, it will give the impetus to development of many alternatives, which 
Table 1. Review of literature on the rewards, creativity and innovation.

\begin{tabular}{|c|c|c|c|}
\hline Authors & Focus & Discussion & Interpretation \\
\hline $\begin{array}{l}{[32][33][34]} \\
{[35][36]}\end{array}$ & $\begin{array}{l}\text { Theories underpinning } \\
\text { rewards for innovation }\end{array}$ & $\begin{array}{l}\text { Agency theory strategic human resources } \\
\text { management. }\end{array}$ & $\begin{array}{l}\text { There are various conceptual themes underpinning } \\
\text { reward and innovation concepts. }\end{array}$ \\
\hline [5] [37]-[46] & $\begin{array}{l}\text { Rewarding practices } \\
\text { that promotes } \\
\text { innovation }\end{array}$ & $\begin{array}{l}\text { Rewards and various rewarding practices positively } \\
\text { impact innovation. Both financial and non-financial } \\
\text { rewards are recorded as positively impacting } \\
\text { innovation. Primary among them are monetary } \\
\text { incentives, promotion, and management } \\
\text { recognition. Intrinsic and extrinsic rewards are } \\
\text { interchangeably for monetary and non-monetary } \\
\text { rewards. }\end{array}$ & $\begin{array}{l}\text { It is well documented through various researches on } \\
\text { rewards that positively impact innovation. Although } \\
\text { most of research agree why innovation should be } \\
\text { awarded, they struggle to explain what should be } \\
\text { rewarded as innovation is a multistage and complex } \\
\text { process. Additionally, when should be innovation } \\
\text { rewarded, is also an intriguing question among the } \\
\text { scholars. }\end{array}$ \\
\hline [12] [46] & $\begin{array}{l}\text { Rewards inhibiting } \\
\text { innovation }\end{array}$ & $\begin{array}{l}\text { Employees abandon work on more challenging } \\
\text { ideas and focus on lower risk incremental } \\
\text { innovation to increase their chances of receiving } \\
\text { monetary rewards. Evidences also suggest that it } \\
\text { leads to a decreased innovation capacity. }\end{array}$ & $\begin{array}{l}\text { Reward is a double-edged sword. Although it has } \\
\text { shown to be of benefit in situations like idea } \\
\text { generation, its benefits are limited. Extrinsic and } \\
\text { monetary rewards "crowd out" intrinsic parts. As a } \\
\text { result, lower motivation for innovation. }\end{array}$ \\
\hline [4] [47] [48] & $\begin{array}{l}\text { Administration of } \\
\text { monetary versus } \\
\text { non-monitory rewards }\end{array}$ & $\begin{array}{l}\text { Both monetary and non-monetary rewards are } \\
\text { linked to innovation, but are difficult to administer. } \\
\text { Some rewards systems are transparent, while others } \\
\text { are translucent. Quantity of ideas is linked to } \\
\text { non-monetary rewards. The quality of ideas is } \\
\text { important since it is mostly linked to non-monetary } \\
\text { rewards. }\end{array}$ & $\begin{array}{l}\text { Rewards mean different things to different people } \\
\text { and hence a recipe for rewarding innovation is } \\
\text { difficult to prescribe. Employees can self-determine } \\
\text { their reward choices. Rewards can be linked to } \\
\text { innovation objectives, innovation stages, level of } \\
\text { contribution and degree of innovation. }\end{array}$ \\
\hline [49] & $\begin{array}{l}\text { Rewards linked to } \\
\text { different types of } \\
\text { innovation }\end{array}$ & $\begin{array}{l}\text { Intrinsic reward is linked to radical innovation, } \\
\text { whereas extrinsic reward is linked to incremental } \\
\text { innovation and diminishing innovation speed. } \\
\text { These research findings are linked to quality of } \\
\text { ideas leading to radical innovation. }\end{array}$ & $\begin{array}{l}\text { Although radical innovation is shown to have } \\
\text { greater impact on customers, markets and } \\
\text { competition, organizations can determine their } \\
\text { innovation objectives. Incremental innovation } \\
\text { and extrinsic rewards linked to it can be a genuine } \\
\text { innovation objective. }\end{array}$ \\
\hline [50] & $\begin{array}{l}\text { Rewards linked to } \\
\text { different stages of } \\
\text { innovation }\end{array}$ & $\begin{array}{l}\text { Rewards can be linked to different stages of } \\
\text { innovation such as opportunity finding, problem } \\
\text { and solution findings. }\end{array}$ & $\begin{array}{l}\text { Innovation is a multistage process. It starts with } \\
\text { creativity and ends with commercialization of the } \\
\text { innovation outputs. Rewards linked to different } \\
\text { stages helps to design meaningful rewards, } \\
\text { according to the contributions made by employees. }\end{array}$ \\
\hline [51] & $\begin{array}{l}\text { Rewarding external } \\
\text { stakeholder for } \\
\text { innovation }\end{array}$ & $\begin{array}{l}\text { Suppliers and distributors should be part of the } \\
\text { reward system of innovation. }\end{array}$ & $\begin{array}{l}\text { Innovation is not limited to only employees but } \\
\text { external stakeholders bring new perspective to the } \\
\text { organization and hence should be rewarded. }\end{array}$ \\
\hline [52] & $\begin{array}{l}\text { Rewarding beliefs and } \\
\text { cultural traits }\end{array}$ & $\begin{array}{l}\text { Rewarding beliefs and cultural traits rather than } \\
\text { innovation. }\end{array}$ & $\begin{array}{l}\text { This stream of research believes that without a } \\
\text { culture of creativity and innovation, rewards do not } \\
\text { hold any meaning. In such scenarios innovation is } \\
\text { just an event rather than sustainable. }\end{array}$ \\
\hline [48] & $\begin{array}{l}\text { Reward creativity or } \\
\text { rewarding innovation }\end{array}$ & $\begin{array}{l}\text { Reward idea management as it is the core of } \\
\text { innovation process. }\end{array}$ & $\begin{array}{l}\text { Since ideas are the seed of innovation ideas should } \\
\text { be rewarded. However, the issue with this argument } \\
\text { is al ideas do not result in innovation and hence are } \\
\text { we rewarding just the effort or the outcomes of those } \\
\text { efforts. }\end{array}$ \\
\hline [53] & $\begin{array}{l}\text { Rewards linked to job } \\
\text { design }\end{array}$ & $\begin{array}{l}\text { Rewards are useful only for routine jobs and } \\
\text { employees have no sense of control and ownership. } \\
\text { Extrinsic reward programs given them a sense of } \\
\text { ownership and being valued. }\end{array}$ & $\begin{array}{l}\text { Rewards should be ideally linked to job design, } \\
\text { which makes it consistent and integrated to work } \\
\text { practices, rather than an occasional or external } \\
\text { process. }\end{array}$ \\
\hline [53] [54] & $\begin{array}{l}\text { Rewards linked to } \\
\text { different personality } \\
\text { types }\end{array}$ & $\begin{array}{l}\text { Highly motivated employees are not motivated by } \\
\text { extrinsic rewards. Threat or reward appraisals do } \\
\text { not work well with these employees. On the other } \\
\text { hand, challenge appraisals are more meaningful to } \\
\text { them. }\end{array}$ & $\begin{array}{l}\text { Rewards are a stimulus. Creative and innovative } \\
\text { urge exists in all, it is important to harness them. } \\
\text { Rewards can be designed based on individual } \\
\text { considerations. }\end{array}$ \\
\hline
\end{tabular}




\section{Continued}

\begin{tabular}{|c|c|c|c|}
\hline [5] & Degree of reward & $\begin{array}{l}\text { Degree of reward determines the innovation. } \\
\text { Bigger reward does not necessarily lead to more } \\
\text { innovation. In fact, it reduces innovation. }\end{array}$ & $\begin{array}{l}\text { High powered rewards may produce a flood of ideas } \\
\text { but may not be of high quality. The focus shifts to } \\
\text { rewards rather than quality of ideas. }\end{array}$ \\
\hline [59] & $\begin{array}{l}\text { New reward systems } \\
\text { for innovation }\end{array}$ & $\begin{array}{l}\text { Copyrights and patents as an appropriate reward } \\
\text { for innovation }\end{array}$ & $\begin{array}{l}\text { Such rewards enhance motivation and ownership to } \\
\text { the employees. }\end{array}$ \\
\hline
\end{tabular}

is essential for innovation. The degree of reward should increase with the results of innovation. In doing so, the reward systems will clearly demarcate the degree of rewards between efforts and outcomes. The debate on the utility of extrinsic and intrinsic rewards is not yet resolved. Firms should design rewards in consultation with employees taking feedback on what types of rewards are more meaningful to them. Finally, the paradigmatic divide on the question of whether rewards promote or prohibit a culture of innovation also begs for further empirical research. In this perspective, the current and past works have yet to concretely examine and explore issues of ethics and organizational justice in determining the effectiveness of rewards within an ecosystem of innovation. The current literature has yet to answer this array of questions conclusively. This question has the biggest implications for firms. It is thus not just the responsibility of research community to answer this question, but firms should come forward and present evidence of what works and what does not. A closer interaction between researchers and firms is needed to answer this question. Until then, the proposition that rewards promote innovation holds true. Most earlier studies also banked on quantitative techniques which focus on finding a relationship between rewards and innovation. Identifying the right timing, the process, the right system and culture as well as the right talents to offer the rewards may require an in-depth qualitative work.

\section{Conflicts of Interest}

The authors declare no conflicts of interest regarding the publication of this paper.

\section{References}

[1] Sanders, K., Jorgensen, F., Shipton, H., Van Rossenberg, Y., Cunha, R., Li, X., Rodrigues, R., Wong, S.I. and Dysvik, A. (2018) Performance-Based Rewards and Innovative Behaviors. Human Resource Management, 57, 1455-1468. https://doi.org/10.1002/hrm.21918

[2] Maurer, I. (2010) How to Build Trust in Inter-Organizational Projects: The Impact of Project Staffing and Project Rewards on the Formation of Trust, Knowledge Acquisition and Product Innovation. International Journal of Project Management, 28, 629-637. https://doi.org/10.1016/j.ijproman.2009.11.006 
[3] Lazonick, W. and Mazzucato, M. (2013) The Risk-Reward Nexus in the Innovation-Inequality Relationship: Who Takes the Risks? Who Gets the Rewards? Industrial and Corporate Change, 22, 1093-1128. https://doi.org/10.1093/icc/dtt019

[4] Hogan, S.J. and Coote, L.V. (2014) Organizational Culture, Innovation, and Performance: A Test of Schein's Model. Journal of Business Research, 67, 1609-1621. https://doi.org/10.1016/j.jbusres.2013.09.007

[5] Baumann, O. and Stieglitz, N. (2014) Rewarding Value-Creating Ideas in Organizations: The Power of Low-Powered Incentives. Strategic Management Journal, 35, 358-375. https://doi.org/10.1002/smj.2093

[6] De Clercq, D., Thongpapanl, N. and Dimov, D. (2015) Structural and Relational Influences on the Role of Reward Interdependence in Product Innovation. R\&D Management, 45, 527-548. https://doi.org/10.1111/radm.12090

[7] Buljubasic, T. (2013) Rewarding Innovation-Influence of Rewarding System to the Innovation. The International Society for Professional Innovation Management (ISPIM), Manchester.

[8] Paulini, M., Maher, M.L. and Murty, P. (2014) Motivating Participation in Online Innovation Communities. International Journal of Web Based Communities, 10, 94-114. https://doi.org/10.1504/IJWBC.2014.058388

[9] Eisenberger, R. and Byron, K. (2011) Rewards and Creativity. In: Runco, M.A. and Pritzker, S.R., Eds., Encyclopedia of Creativity, 2nd Edition, Elsevier, Amsterdam, 313-318. https://doi.org/10.1016/B978-0-12-375038-9.00188-6

[10] Yoon, H.J., Sung, S.Y. and Choi, J.N. (2015) Mechanisms Underlying Creative Performance: Employee Perceptions of Intrinsic and Extrinsic Rewards for Creativity. Social Behavior and Personality: An International Journal, 43, 1161-1179. https://doi.org/10.2224/sbp.2015.43.7.1161

[11] Dziallas, M. and Blind, K. (2019) Innovation Indicators throughout the Innovation Process: An Extensive Literature Analysis. Technovation, 80-81, 3-19. https://doi.org/10.1016/j.technovation.2018.05.005

[12] Dewangan, V. and Godse, M. (2014) Towards a Holistic Enterprise Innovation Performance Measurement System. Technovation, 34, 536-545. https://doi.org/10.1016/j.technovation.2014.04.002

[13] Burroughs, J.E., Dahl, D.W., Moreau, C.P., Chattopadhyay, A. and Gorn, G.J. (2011) Facilitating and Rewarding Creativity during New Product Development. Journal of Marketing, 75, 53-67. https://doi.org/10.1509/jmkg.75.4.53

[14] Chion, S. and Charles, V. (2018) The Risk and Reward Management in Innovation Portfolios: A Markovian Approach. Croatian Operational Research Review, 9, 165. https://doi.org/10.17535/crorr.2018.0013

[15] Eisenberger, R. and Shanock, L. (2003) Rewards, Intrinsic Motivation and Creativity: A Case Study of Conceptual and Methodological Isolation. Creativity Research Journal, 15, 121-130. https://doi.org/10.1207/S15326934CRJ152\&3_02

[16] O'Shea, D. and Buckley, F. (2007) Towards an Integrative Model of Creativity and Innovation in Organizations: A Psychological Perspective. The Irish Journal of Psychology, 28, 101-128. https://doi.org/10.1080/03033910.2007.10446254

[17] Lin., C.Y. and Liu, F. (2012) A Cross Level Analysis of Organizational Creativity Climate and Perceived Innovation: The Mediating Effect of Work Motivation. European Journal of Innovation Management, 15, 55-76. https://doi.org/10.1108/14601061211192834

[18] Salter, A., Criscuolo, P. and Ter Wal, A.L. (2014) Coping with Open Innovation: 
Responding to the Challenges of External Engagement in R\&D. California Management Review, 56, 77-94. https://doi.org/10.1525/cmr.2014.56.2.77

[19] Jaiswal, N.K. and Dhar, R.L. (2015) Transformational Leadership, Innovation Climate, Creative Self-Efficacy, and Employee Creativity: A Multilevel Study. International Journal of Hospitality Management, 51, 30-41.

https://doi.org/10.1016/j.ijhm.2015.07.002

[20] Chaudoir, S.R., Dugan, A.G. and Barr, C.H. (2013) Measuring Factors Affecting Implementation of Health Innovations: A Systematic Review of Structural, Organizational, Provider, Patient, and Innovation Level Measures. Implementation Science, 8, 22. https://doi.org/10.1186/1748-5908-8-22

[21] Eling, K., Griffin, A. and Langerak, F. (2016) Consistency Matters in Formally Selecting Incremental and Radical New Product Ideas for Advancement. Journal of Product Innovation Management, 33, 20-33. https://doi.org/10.1111/jpim.12320

[22] Van, K., Oorschot, K., Eling, F. and Langerak, F. (2018) Measuring the Known to Manage the Unknown. How to Choose the Gate Timing Strategy in NPD Projects? Journal of Product Innovation Management, 35, 164-183. https://doi.org/10.1111/jpim.12383

[23] Bhatnagar, J. (2014) Mediator Analysis in the Management of Innovation in Indian Knowledge Workers: The Role of Perceived Supervisor Support, Psychological Contract, Reward and Recognition, and Turnover Intention. The International Journal of Human Resource Management, 25, 1395-1416. https://doi.org/10.1080/09585192.2013.870312

[24] Rajiani, I., Musa, H. and Hardjono, B. (2016) Ability, Motivation, and Opportunity as Determinants of Green Human Resources Management Innovation. Research Journal of Business Management, 10, 51-57. https://doi.org/10.3923/rjbm.2016.51.57

[25] Mahmoud, K. and Fadlemula, E. (2017) Reward-Based Crowdfunding Technological Projects Determinants of Success: A Quantitative Study. The Journal of Entrepreneurial Finance, 19, Article 6.

[26] Anderson, N., Potočnik, K. and Zhou, J. (2014) Innovation and Creativity in Organizations: A State-of-the-Science Review, Prospective Commentary, and Guiding Framework. Journal of Management, 40, 1297-1333. https://doi.org/10.1177/0149206314527128

[27] Ederer, F. and Manso, G. (2013) Is Pay for Performance Detrimental to Innovation? Management Science, 59, 1496-1513. https://doi.org/10.1287/mnsc.1120.1683

[28] Prajogo, D.I. (2016) The Strategic Fit between Innovation Strategies and Business Environment in Delivering Business Performance. International Journal of Production Economics, 171, 241-249. https://doi.org/10.1016/j.ijpe.2015.07.037

[29] Abdul Rahim, R., Nasir, M., Azrin, N., Mat Yusof, M. and Ahmad, N.L. (2013) Reward and Employee's Creativity: Case of Manufacturing Organization. Global Journal of Business and Social Science Review, 1, 10-17.

[30] Sarooghi, H., Libaers, D. and Burkemper, A. (2015) Examining the Relationship between Creativity and Innovation: A Meta-Analysis of Organizational, Cultural, and Environmental Factors. Journal of Business Venturing, 30, 714-731. https://doi.org/10.1016/j.jbusvent.2014.12.003

[31] Al-Mahdawiy, B. (2016) Understanding the Impact of Rewards on Employees' Creativity and Innovation: A Literature Review Study.

[32] Fama, E. (1980) Agency Problems and the Theory of the Firm. Journal of Political Economy, 88, 288-307. https://doi.org/10.1086/260866 
[33] Eisenhardt, K.M. (1989) Building Theories from Case Study Research. Academy of Management Review, 14, 532-550. https://doi.org/10.5465/amr.1989.4308385

[34] Holbeche, L. (2009) Aligning Human Resources and Business Strategy. 2nd Edition, Butterworth Heinemann, Oxford. https://doi.org/10.4324/9780080941424

[35] Dutra, J.D. and Hipólito, J.A.M. (2012) Remuneração e recompensas. Elsevier, Rio de Janeiro.

[36] Bratton, J. and Gold, J. (2012) Human Resource Management: Theory and Practice. 5th Edition, Palgrave Macmillan, Basingstoke.

https://doi.org/10.1007/978-1-137-00095-8

[37] Barczak, G., Griffin, A. and Kahn, K.B. (2009) Perspective: Trends and Drivers of Success in NPD Practices: Results of the 2003 PDMA Best Practices Study. Journal of Product Innovation Management, 26, 3-23. https://doi.org/10.1111/j.1540-5885.2009.00331.x

[38] Calamel, L., Defelix, C., Picq, T. and Retour, D. (2012) Inter-Organizational Projects in French Innovation Clusters: The Construction of Collaboration. International Journal of Project Management, 30, 48-59. https://doi.org/10.1016/j.ijproman.2011.03.001

[39] Davila, T., Epstein, M.J. and Shelton, R. (2006) Making Innovation Work: How to Manage It, Measure It, and Profit from It. Prentice Hall, Upper Saddle River.

[40] Jiang, J., Wang, S. and Zhao, S. (2012) Does HRM Facilitate Employee Creativity and Organizational Innovation? A Study of Chinese Firms. International Journal of Human Resource Management, 23, 4025-4047. https://doi.org/10.1080/09585192.2012.690567

[41] Goffin, K. and Mitchell, R. (2010) Innovation Management: Strategy and Implementation Using the Pentathlon Framework. 2nd Edition, Palgrave Macmillan, Basingstoke. https://doi.org/10.1007/978-1-137-04752-6

[42] Hamel, G. (2007) The Future of Management. Harvard Business School Press, Boston.

[43] Kunz, J. (2010) Performance Evaluation in Multistep Processes: A Comparison of Evaluation Types with Special Emphasis on R\&D. IEEE Transaction on Engineering Management, 57, 405-415. https://doi.org/10.1109/TEM.2010.2040744

[44] Deci, E.L. and Ryan, R.M. (1985) Intrinsic Motivation and Self-Determination in Human Behavior. Plenum, New York. https://doi.org/10.1007/978-1-4899-2271-7

[45] Frey, B.S. and Jegen, R. (2001) Motivation Crowding Theory. Journal of Economic Surveys, 15, 589-611. https://doi.org/10.1111/1467-6419.00150

[46] Jimenéz-Jimenéz, D. and Sanz-Valle, R. (2008) Could HRM Support Organizational Innovation? International Journal of Human Resource Management, 19, 1208-1221. https://doi.org/10.1080/09585190802109952

[47] Amabile, T. (1998) How to Kill Creativity. Harvard Business Review, 76, 76-87.

[48] Baumgartner, J. (2007) Rewarding Innovation. Report 103. https://www.creativejeffrey.com/creative/rewards.php?topic=creative

[49] Behrens, J. and Patzelt, H. (2018) Incentives, Resources and Combinations of Innovation Radicalness and Innovation Speed. Federal Reserve Bank of St Louis, St. Louis. https://doi.org/10.1111/1467-8551.12265

[50] Kuczmarski, S. and Kuczmarski, T. (2009) How Rewards Fuel or Fail Innovation. Strategic HR Review, 18, 8-12. https://doi.org/10.1108/SHR-11-2018-0091

[51] Sumo, R., Van, D., Arjan, V.W. and Bode, C. (2016) Fostering Incremental and 
Radical Innovation through Performance-Based Contracting in Buyer-Supplier Relationships. International Journal of Operations \& Production Management, 36, 1482-1503. https://doi.org/10.1108/IJOPM-05-2015-0305

[52] Marx, R., Soares, J.P.R.F. and da Silva Barros, L.S. (2016) Organizational Context Variables to Be Considered in the Reward System Design Oriented to Product Innovation. Revista Brasileira de Gestao de Negocios, 18, 267-289.

https://www.researchgate.net/publication/305274450_Organizational_context_varia bles_to_be_considered_in_the_reward_system_design_oriented_to_product_innov ation https://doi.org/10.7819/rbgn.v18i60.2822

[53] Baer, M., Oldham, G.R. and Cummings, A. (2003) Rewarding Creativity: When Does It Really Matter? The Leadership Quarterly, 14, 569-586. https://doi.org/10.1016/S1048-9843(03)00052-3

[54] Li, F., Chen, T. and Lai, X. (2017) How Does a Reward for Creativity Program Benefit or Frustrate Employee Creative Performance? The Perspective of Transactional Model of Stress and Coping. Group and Organization Management, 43, 138-175. https://doi.org/10.1177/1059601116688612

[55] Wright, P.M. and Nishii, L.H. (2007) Strategic HRM and Organizational Behavior: Integrating Multiple Levels of Analysis (CAHRS Working Paper \#07-03). Centre for Advanced Human Resource Studies, School of Industrial and Labor Relations, Cornell University, Ithaca.

[56] Malik, M.A.R., Butt, A.N. and Choi, J.N. (2015) Rewards and Employee Creative Performance: Moderating Effects of Creative Self-Efficacy, Reward Importance, and Locus of Control. Journal of Organizational Behavior, 36, 59-74. https://doi.org/10.1002/job.1943

[57] Byron, K. and Khazanchi, S. (2012) Rewards and Creative Performance: A Meta-Analytic Test of Theoretically Derived Hypotheses. Psychological Bulletin, 138, 809-830. https://doi.org/10.1037/a0027652

[58] Deng, H., Leung, K. and Zhao, Y. (2017) Is Perceived Creativity-Reward Contingency Good for Creativity? The Role of Challenge and Threat Appraisals. Human Resource Management, 56, 551-709. https://doi.org/10.1002/hrm.21795

[59] Zimmerman, D.L. (2011) Copyrights as Incentives: Did We Just Imagine That? Theoretical Inquiries in Law, 12, 30-58. https://doi.org/10.2202/1565-3404.1262 